\title{
Dialogue of Modernity and Tradition in the Landscapes by Bronisław Jamontt from the Interwar Period
}

\section{Małgorzata Geron}

Nicolaus Copernicus University in Toruń mgeron@umk.pl

A fascination with nature accompanied Bronisław Jamontt throughout all stages of his artistic creation. His early work was characterised by the truthful depiction of reality. Contact with the Krakow-Zakopane creative community influenced the creation of efficient works in the selection of formal means, allowing him to record feelings evoked by nature. In the 1920 s, Jamontt, inspired by the search for avant-garde artists, created fantastic landscapes filled with rock blocks placed in cosmic space. The transformation of shapes was accompanied by an unreal colour range, additionally leading to a mood of anxiety and mystery. From the 1930s, the artist again began to emphasise the realistic element, allowing the creation of decorative landscapes, composed on the basis of sketches, referring to the romantic vision of nature.

Keywords: Bronisław Jamontt, painting, landscape, interwar period, Vilnius artistic environment, Vilnius Drawing School, Faculty of Fine Arts of Stephen Báthory University in Vilnius. 
Bronisław Jamontt (1886-1957) belongs to a group of outstanding landscape painters, whose artistic biography was first associated with Vilnius and, following World War II, Toruń1. The artist's oeuvre is yet to be appreciated in the form of a monograph. References to his work appeared chiefly on the occasion of exhibitions of the Vilnius Society of Visual Artists. Similarly, the artist's solo exhibitions became a pretext for the characterisation of his works, as evidenced by the articles by Wacław Husarski (1934), Jerzy Hoppen, Kazimierz Kieniewicz, Leon Śmieciuszewski (1939), Jadwiga Puciata-Pawłowska, Jerzy Remer $(1947,1955)^{2}$, to mention but a few. On the 50th anniversary of Jamontt's passing, Jan Kotłowski conducted a visual and illustrative analysis of the artist's legacy3. In 2011, the District Museum in Torun hosted the artist's last exhibition. The presentation was accompanied by a catalogue by Agata Rissmann containing, in addition to a general discussion of Jamontt's work, a calendar, as well as a list of all his exhibitions and a detailed bibliography ${ }^{4}$. This paper explores the changes in the artist's painting that took place during the Vilnius period in the context of inspiration with realism, early expressionism, symbolism, the avant-garde and the works by the old masters.

Jamontt began his artistic education before 1908 at the Vilnius Drawing School, where he had the opportunity to learn the fundamentals

1 Hanna Kubaszewska, M. Liczbińska, Hanna Załęska, "Jamontt Bronisław”, in: Stownik artystów polskich i w Polsce działających, Vol. III, ed. Jolanta Maurin-Białostocka, WrocławWarszawa-Kraków-Gdańsk, 1979, pp. 188-191; Jan Kotłowski, “Bronisław Jamontt”, in: https://www. bu.umk.pl/bronislaw-jamontt.

2 W. H. [Husarski Wacław], "Z Zachęty. Bronisław Jamontt” [From Zachęta Gallery], in: Tygodnik Illustrowany, 1934, No. 22, p. 432; Jerzy Hoppen, "Artyzm Bronisława Jamontta” [Bronisław Jamontt artistry], in: Stowo, 1939, No. 42, p. 11; Kazimierz Kieniewicz, "Zbiorowa wystawa prac Bronisława Jamontta” [Collective exhibition of works by Bronisław Jamontt], in: Stowo, 1939, No. 37, p. 7; Jerzy Hoppen, "Bronisław Jamontt. Z powodu jubileuszowej wystawy w Toruniu" [Bronisław Jamontt. Because of the jubilee exhibition in Toruń], in: Arkona, 1947, No. 4-5, pp. 16-17; Jadwiga Puciata-Pawłowska, "Krajobraz B. Jamontta (na marginesie wystawy w toruńskim Domu Plastyków)" [B. Jamontt's landscape (in the fringe of the exhibition at the House of Artists in Toruń)], in: Gtos Pomorza, (27.04), 1947, p. 4; Jerzy Remer, "Oblicze artystyczne B. Jamontta” [The artistic look of B. Jamontt], in: Głos Pomorza, (14.04), 1947; Jadwiga Puciata-Pawłowska, "Droga Bronisława Jamontta" [Bronisław Jamontt's path], in: Pomorze, 1955, No. 3, p. 15.

3 Jan Kotłowski, "Z graficznej i rysunkowej twórczości Bronisława Jamontta” [From the graphic and drawings of Bronisław Jamontt], in: Studia o działalności i zbiorach Biblioteki Uniwersytetu Mikołaja Kopernika, ed. B. Ryszewski, part IV, Torun: Wydawnictwo Uniwersytetu Mikołaja Kopernika, 1991, pp. 37-67.

4 Agata Rissmann, Bronistaw Jamontt 1886-195\%. Malarstwo. Rysunek [Bronisław Jamontt 1886-1957. Painting. Drawing], Toruń: Muzeum Okręgowe w Toruniu, 2011. 
of drawing and painting 5 . His teacher was Ivan Trutnev, who, following an academic convention, alongside religious and mythological compositions and portraits, painted realistic landscapes and sceneries of Vilnius. In 1899, Ivan Rybakov became Trutnev's assistant. Landscapes dominate his works, largely painted outdoors, combining realism with impressionist influences. It seems that he tried to convey these ideas to his students, not only as part of practical classes but also by introducing the issues of modern art through speeches, an example of which is the information about the lecture "Contemporary art. Impressionism and decadence" ${ }^{6}$. In the years 1908-1910, Jamontt studied law in St. Petersburg and simultaneously attended drawing courses taught at the Academy of Fine Arts. In 1909, the artist travelled to Krakow and Zakopane.

It seems that these first experiences influenced twenty-year-old Jamontt's interest in landscape, and it remained close to him throughout his artistic career. The works created before World War I reveal a variety of influences. Fragment lasu sosnowego [A fragment of a pine forest] (1909, National Museum in Warsaw) [illus. 1], drawn with a nib, draws attention to the meticulous depiction of a forest glade. Motif-wise, it refers to the works by Ivan Shishkin; Jamontt made a copy of his work, referred to as "Wnętrze lasu Szyszkina" [The interior of the Shishkin Forest], back in 1904". His attachment to realism is further revealed by the pencil drawing, Jezioro $w$ Trockiem [Lake in Trakai] (1911, National Museum in Warsaw). The artist planned to use this as the basis of a painted version. This intention is confirmed by information about the colours of individual parts of the composition. Initially, the relationship with the Krakow-Zakopane milieu drew the artist's attention to the achievements of Stanisław Wyspiański, who died in 1907. In addition to drawings in charcoal depicting individual plants (Konwalie [Lilies-of-the-valley], Lilie [Lilies], Mlecze [Dandelions], 1911, National Museum in Warsaw), characterised by the decorativeness of the motif taken from nature and reminiscent of Wyspiański's polychrome from the Franciscan Church in Cracow, Jamontt made copies of the artist's creations (Wieża zegarowa na Wawelu w Krakowie / Kopia z Wyspiańskiego [Clock

5 Jolanta Širkaitè, Académie de Vilna. Vilniaus piešimo mokykla / Vilnius Drawing School 1866-1915: Parodos katalogas / Exhibition Catalogue, Nacionalè dailès galerija, $2017 \mathrm{~m}$. spalio 4 d. - lapkričio 26 d., Vilnius: Lietuvos kultūros tyrimų institutas, 2017, p. 188.

6 Ibid., pp. 30-31.

7 After: Agata Rissmann, op. cit., p. 30. 


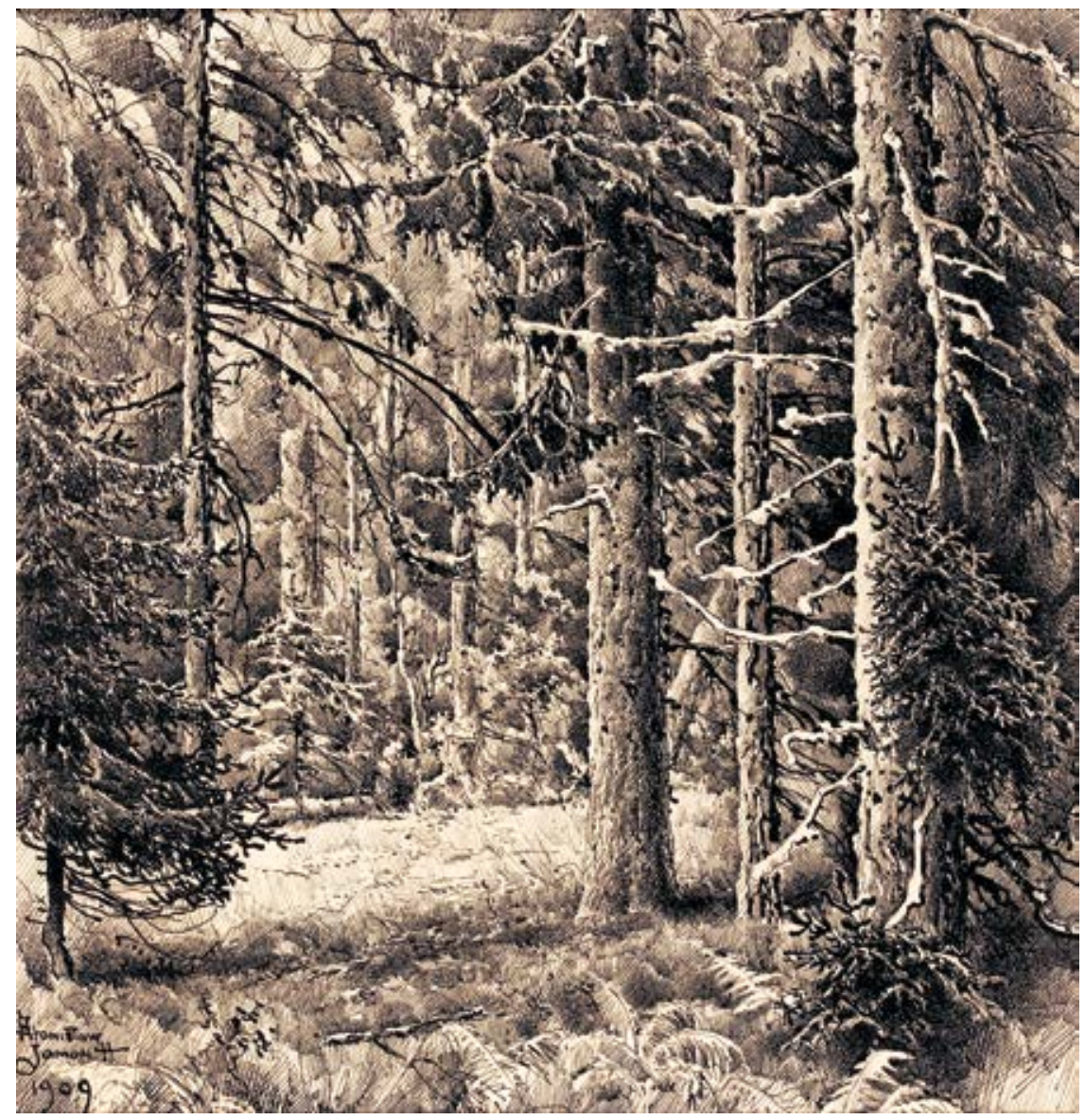

1.

Bronisław Jamontt, Fragment of a Pine Forest, 1909, Bronisławas Jamonttas, Pušyno fragmentas, 1909 ink, nib, paper, National Museum in Warsaw

Tower in Wawel in Krakow / Copy from Wyspiański], 1910, National Museum in Warsaw) [illus. 2]. This style, characteristic of Wyspiański, can be found in the drawing Motyw ze starego Wilna [A motif from the Old Vilnius] (1909, National Museum in Warsaw). In this case, the characteristic decorativeness is dominated by a thick, hectic line defining the planes filled with smudged charcoal. Stanisławski passed away the same year as Wyspiański did. As the Head of the "landscape class," since 1897, of the School of Fine 
Arts in Krakow (the Academy since 1900), he tutored a whole generation of talented landscape painters. Jamontt's affiliation with the "Stanisławski school” was particularly evident in his paintings dated 1909-1915, drawing attention to the synthesis of form, constructed with broad, dynamic, and at times sketchy brush strokes.

Additionally, the notion of expression is enhanced by the mode by which the paint is applied, with thick, often overlapping streaks, emphasising the simplified shapes, thus creating interesting texture effects. With these measures, the artist created far-reaching landscapes, separated by horizontal zones of fields, meadows, and forests (Pejzaż z taka $i$ drzewami [A landscape with meadow and trees], circa 1909-1915, District Museum in Toruń), or engulfed by clumps of green rural huts (Pejzaż z chata wśród drzew [A landscape with a hut among trees], circa 1909-1915, District Museum in Toruń). Occasionally, the green, yellow, and blue dominating the landscapes are replaced by almost monochrome sets; an illustration here may be the eponymous Wiatrak [A windmill] (1909-1915, District Museum in Toruń). The composition of this miniature work focuses on a single and selected motif to which the whole concept of work is subordinated. A similar artistic vision accompanies the small oil painting Stóg siana na tace [A haystack in the meadow] (1913, National Museum in Warsaw). In this case, the image of nature was summarised into several layouts, built with the help of several colour stripes. The lowered horizon line, marked with a navy blue line, separates the system into two colour zones; the upper, grey-blue one, reflecting the impression of the sunrise and the lower one, suggesting a fragment of a meadow on which the haystack was placed, reduced to a short form.

Following the example of Stanisławski and other artists from the turn of the 19th and 20th centuries who took up the subject of landscapes, nature became a carrier of more in-depth content for Jamontt as well. Nature, often reduced to simple plant motifs or phenomena, constituted a testimony of the artist's feelings. Permeated with spiritual elements, it revealed a feeling of melancholy and transience as well as fear of the destructive force of nature, characteristic of the Young Poland period. Wiesław Juszczak provided an apt portrayal of Stanisławski's works that fit into the 


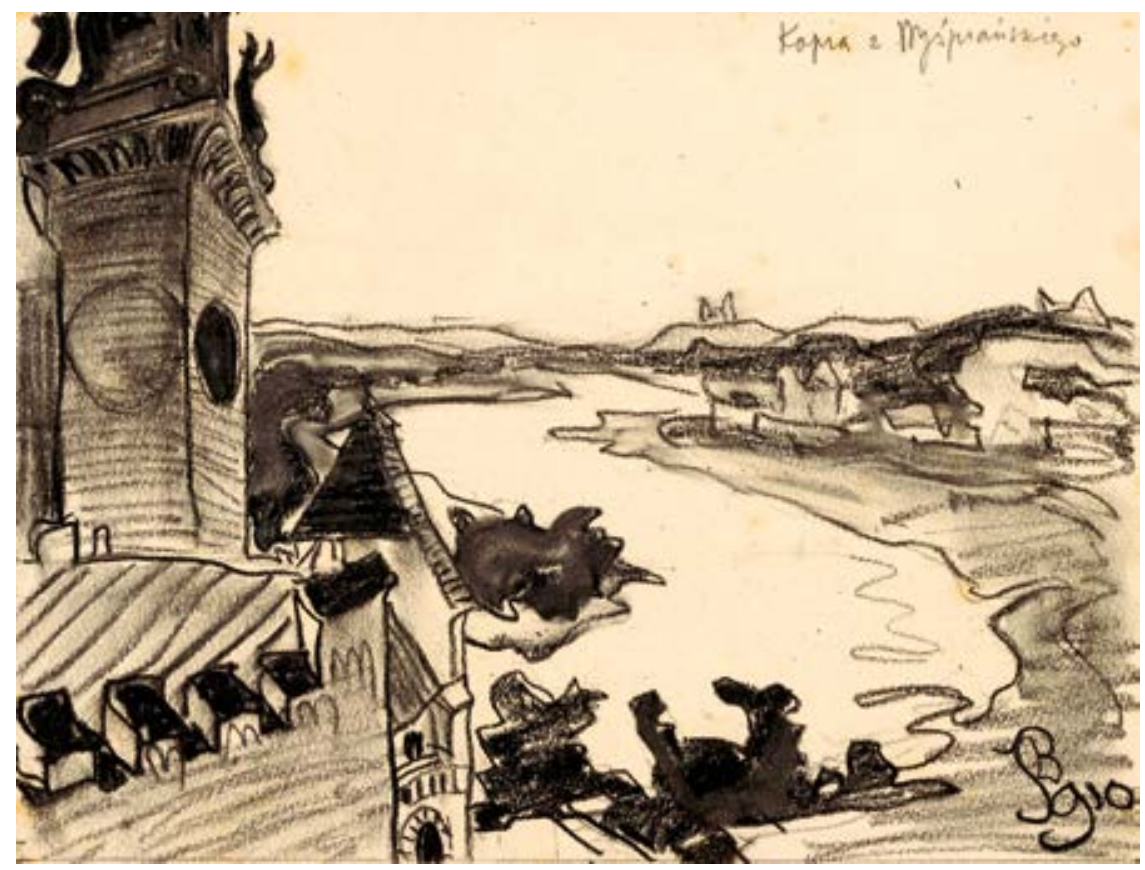

2.

Bronisław Jamontt, Clock Tower in Wawel in Bronisławas Jamonttas, Vavelio varpinè Krokuvoje/ Krakow / Copy from Wyspiański, 1910, crayon, paper, National Museum in Warsaw

Wyspiańskio darbo kopija, 1910

symbolism trend stating that landscape in his oeuvre is "the ground most inclined for development of a symbolic interpretation of reality, as he employed the phenomena that a painter can easily clash with himself [to]convince us of the illusions of this opposition to show us all its groundlessness against the symbolic vision of the world".

In the Polish art of the turn of the century, early expressionism stemmed from the current of symbolism. In the Krakow environment, this tendency was particularly evident in the works by the members of the Group of Five, as well as the works by Wojciech Weiss. The development of this trend was influenced by the opinions of Stanisław Przybyszewski, who, in 1898, moved from Berlin to Krakow, where he published the Confiteor platform containing the famous slogan "art for art's sake" in Życie magazine'.

8 Stefania Krzysztofowicz-Kozakowska, Sztuka Młodej Polski, Kraków: Wydawnictwo Kluszczyński, [2003], p. 178.

9 Stanisław Przybyszewski, "Confiteor”, in: Programy i dyskusje literackie okresu Młodej Polski, ed. Maria Podraza-Kwiatkowska, Wrocław-Warszawa-Kraków-Gdańsk: Zakład Narodowy im. Ossolińskich, 1977, pp. 235-243. 


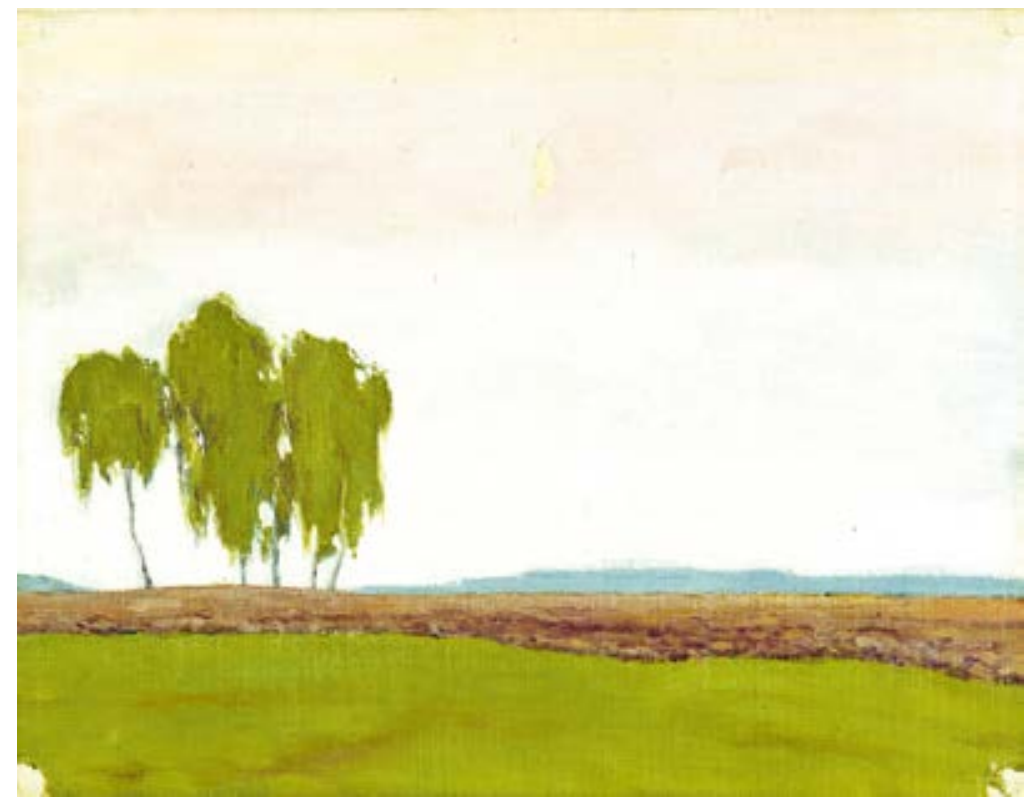

3.

Bronisław Jamontt, Landscape with Birches, ca. 1909-1915, oil, canvas, cardboard, District Museum in Toruń
Bronisławas Jamonttas, Peizažas su beržais, apie 1909-1915

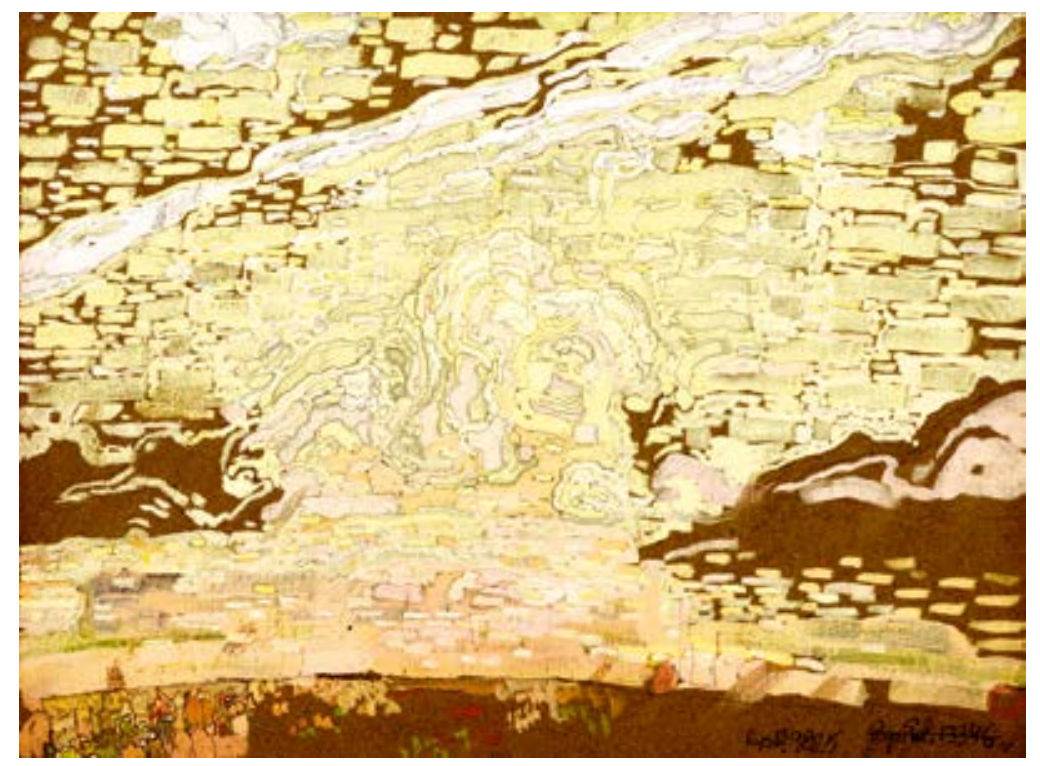

Bronisław Jamontt, Trees, before 1920, gouache, paper, National Museum in Warsaw 
Przybyszewski found the artistic translation of his assumptions in the works by Edvard Munch. Numerous texts devoted to the Norwegian, referred to as the "painter of internal life," serve as a testimony of this analogy. Referring to Munch's landscapes in his collection entitled $\mathrm{Na}$ drogach duszy [On the roads of the soul], he stated: "His landscapes are seen in the soul $\langle\ldots\rangle$, his paintings are the absolute equivalents of certain groups of impressions" ${ }^{\prime 10}$. Thanks to Przybyszewski, Munch's impact began to become noticeable in the works by young Krakow artists. An important position in this group was occupied by Weiss, whose achievements between 1898 and 1905 were characterised by intense expression. Landscapes saturated with feelings of depression and sadness as well as fear, in which nature appears as a destructive force, have gained particular significance. Weiss's oil painting Wieczór [Evening] (around 1900, in a private collection) corresponds to Pejzaz z brzozami [A landscape with birches] (around 1909-1915, District Museum in Toruń) [illus. 3] by Jamontt, copying the shape of jagged tree crowns situated in a disturbingly blank space in the morning.

In 1922 Jamontt took part in the first exhibition of the Vilnius Society of Visual Artists, with which he was associated from the time of its formation until its last presentation in $1934^{11}$. According to an anonymous observer, in the works from the early 1920s: "P. B. Jamontt is slowly beginning to recover (admittedly successfully) from impressionism, giving efforts to creatively construct the whole, such as "landscape in green tones, 'autumn storm' and so forth"12. Probably, these comments referred to works similar to Drzewa [Trees] (National Museum in Warsaw), created before 1920 [illus. 4]. Painted in the technique of gouache, they are rather an impression of a particular motif derived from nature. Whitened yellows and blues, applied with rectangular brushstrokes, dominate the painting, forming a kind of decorative mosaic. The concept of a snowy landscape, also referring to the Art Nouveau exquisite, tuned with white, brings to mind the Bajka zimowa [Winter Fairy Tale] (1904, National Museum in Krakow) by Ferdynand Ruszczyc. It is possible that an example of the signalled changes taking place in Jamontt's work - a copy of a tempera,

10 Stanisław Przybyszewski, Na drogach duszy, Kraków: L. Zwoliński i Spółka, 1900, p. 51.

11 Dariusz Konstantynów, Wileńskie Towarzystwo Artystów Plastyków 1920-1939, Warszawa: Instytut Sztuki Polskiej Akademii Nauk, 2006.

12 "Pierwsza doroczna wystawa Wileńskiego Towarzystwa Artystów Plastyków", in: Potudnie, 1922, No. 3, p. 58. 

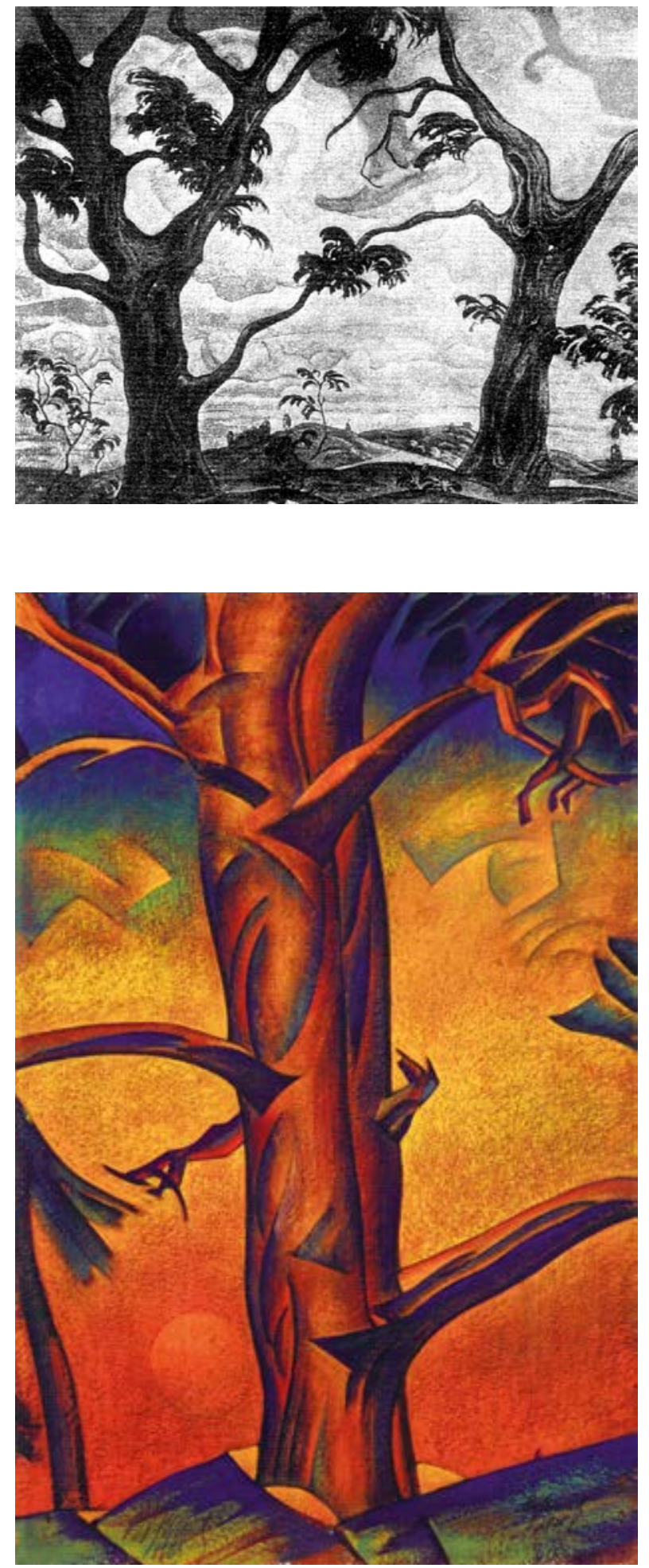

5.

Bronisław Jamontt, Lemon Trees, before 1920 , work lost, copy Potudnie 3, 1922

Bronisławas Jamonttas, Citrinmedžiai, iki 1920, originalas dingęs, kopija Potudnie 3, 1922
Bronisław Jamontt, Moonlit Evening, ca. 1925 , tempera, paper, Leon Wyczółkowski District Museum, Bydgoszez

Bronisławas Jamonttas, Vakaras ménulio šviesoje, apie 1925 
Drzewa cytrynowe [Lemon trees] (missing work), - serve as an illustration of the review [illus. 5]. An anlaysis of it indicates that the artist gave up the impressionist mode of spreading the colour spot in favour of linearism, which is particularly evident in the construction of the eponymous trees. Their form is defined by a clear contour cutting expressionistically bent branches from a light background filled with menacingly swirled clouds, also seen in Ruszczyc's works.

The direction of change is illustrated by subsequent landscapes, which are somewhat imaginary visions. Jamontt returned to the theme of trees in the work Księżycowy wieczór [Moonlit evening] (around 1925, Leon Wyczółkowski District Museum in Bydgoszcz) [illus. 6], which is characterised by a vivid account. The fantastic colour of the trunk, dividing the vertical composition in half, became the primary means of expression. The impression is intensified by the deformation of the shape, emphasising the "rapaciousness" of the branches, cutting off the plane background, gradually passing from the "scorching" sphere of the setting sun, reds, oranges and yellows, to cool greens, and blues. The unreality of this artistic concept was further highlighted by the titles of the works themselves, an example of which is Pejzaz fantastyczny [Fantastic landscape] (around 1922, National Museum in Warsaw) [illus. 7]. The main part of this composition is occupied by giant boulders, reduced to irregular geometric forms, whose construction is further emphasised by strong chiaroscuro. Similar elements can be found in Pejzaz ze skałami [Landscape with rocks] (1922, National Museum in Warsaw) [illus. 8]. The foreground of the gouache is filled with a stone block with sharp edges, with a giant plant towering above, with a red flower bud at the top. The slightly different forms, reminiscent of a rocky coast, occupy subsequent parts of the composition. Above the lowered horizon, heavy clouds are floating, pouring with rain, marked by diagonal streaks, interacting with the diagonally cut structure of the rocks. The artist's collection includes a small drawing indicating a change in the final concept of the work. In the preserved sketch (Pejzaz [Landscape], National Museum in Warsaw), the centre of the composition is occupied by a rock with a rhomboidal shape [illus. 9]. Its angle of inclination is repeated by the tree trunk from which a 
giant leaf and flower stem, introduced into the final version. Krajobraz formistyczny z jeziorem i droga (Krajobraz fantastyczny) [Formist landscape with a lake and road (Fantastic landscape)] is dated 1923-1924 (National Museum in Warsaw) [illus. 10]. The title of the painting refers to the achievements of Formists, a significant artistic group in Polish art, operating in the years 1917-1922. According to Konrad Winkler, a member and monographist of the group, assessing the influence of Formists on other artists, including Jamontt, belonged to this group of artists in whom: "Born out of the instinct of these artists, the creative will is, like in the case of Formists: the will of form"13. Searching for an analogy between the works by Jamontt from the first half of the 1920s and the Formists, similarities arise in the mode reality is processed, subordinated to the simplification and geometry of the form, referring to the search of Paul Cézanne and the Cubists, as well as the use of rhythmic composition combined with expressionist reformation and colours. It is worth mentioning at this point that in 1924 a mock-up of the monument to Adam Mickiewicz by Zbigniew Pronaszko was unveiled in Vilnius, which summed up the artist's relationship with formism. A year earlier, he began short-lived cooperation with the Faculty of Fine Arts of the Stephen Báthory University in Vilnius. In 1921, the New Art Exhibition was opened in Vilnius. It was co-organised by Władysław Strzemiński and Witold Kajruksztis. The experience of cubism, futurism, constructivism and suprematism had a significant impact on the shaping of his artistic attitude. The impact of avant-garde tendencies in the Vilnius circles can also be found in the works by Vladas Drema. Furthermore, the characteristic geometrisation, leading to the formalisation of the form, was also revealed in the urban landscapes of Michał Rouba.

In Jamontt's subsequent works, "cosmic landscapes" were replaced with relatively more natural sceneries. The changes taking place were noted by Kazimiera Adamska-Roubina, who recognised her earlier works as "distant reminiscences of nature," gradually being replaced by "contents introducing more familiar, more vital, less abstract themes"14. The sign of these changes is the gouache Pejzaz z wierzabami [Landscape with willows] (1924, National Museum in Warsaw), subordinated to two almost twin trees, 


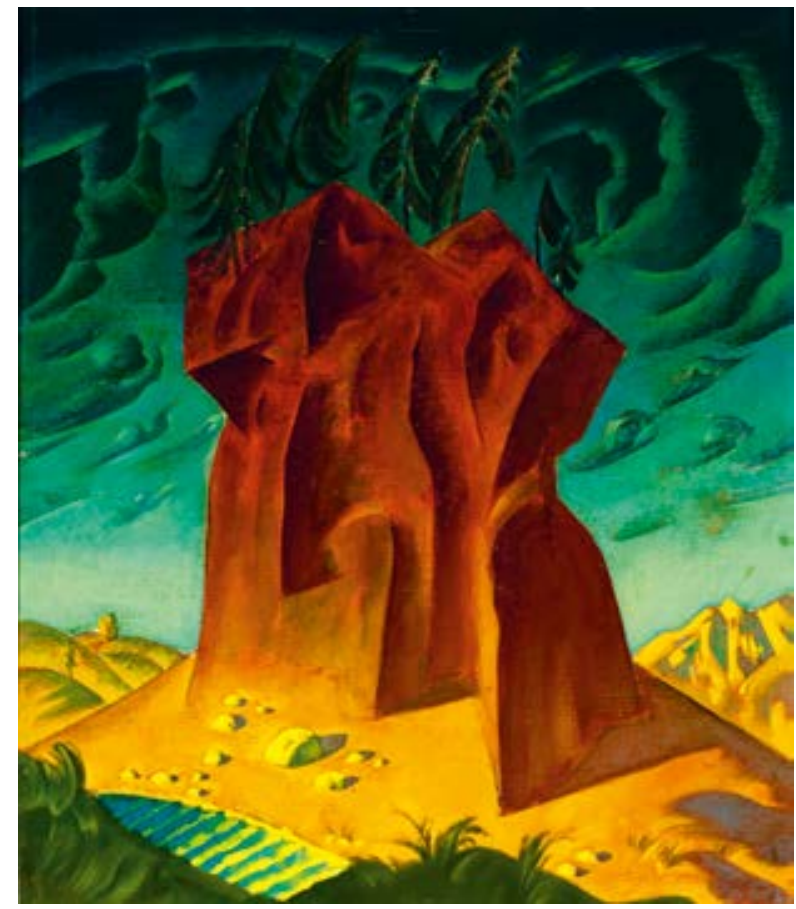

\section{7.}

Bronisław Jamontt, Fantastic Landscape, ca. 1922, oil, canvas,

National Museum in Warsaw

Bronisławas Jamonttas, Fantastinis peizažas, apie 1922

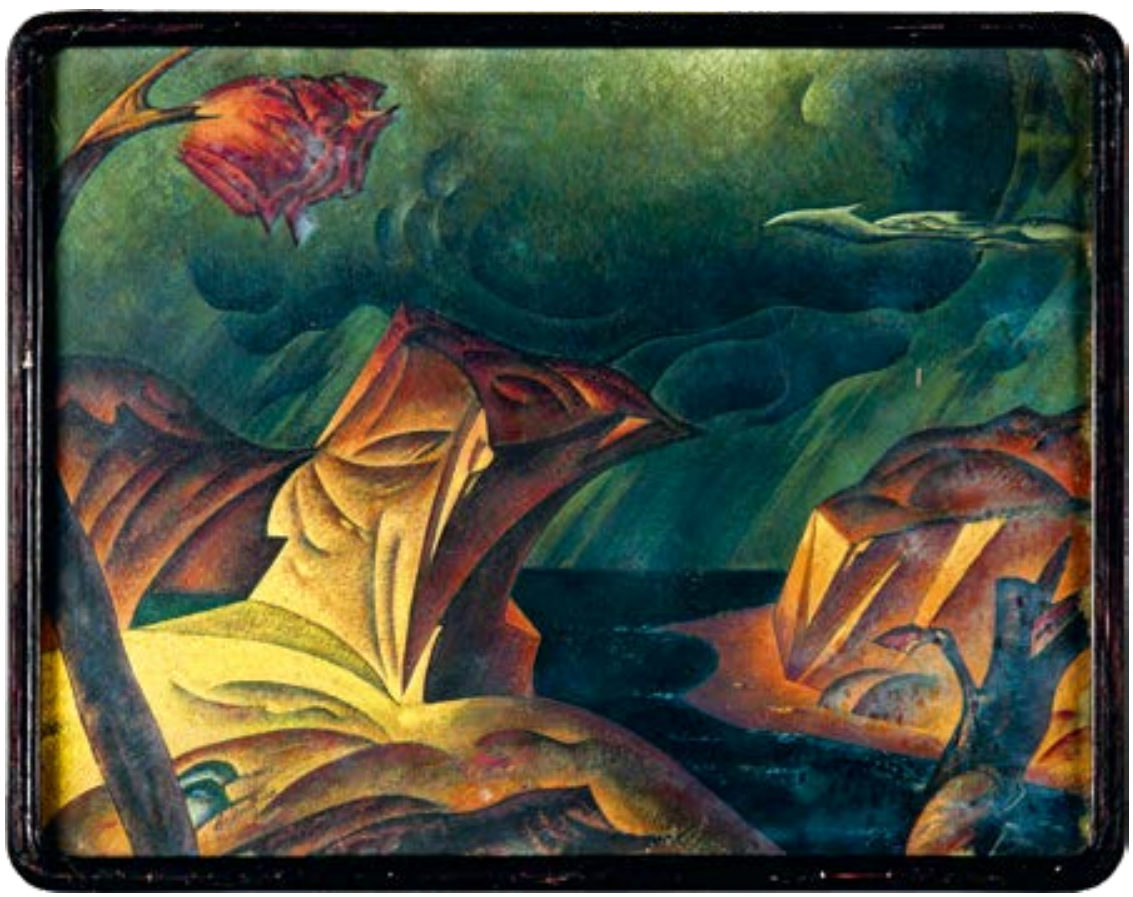

Bronisław Jamontt, Landscape with Rocks, 1922, pencil, paper, National Museum in Warsaw

Bronisławas Jamonttas, Peizažas su uolomis, 1922 


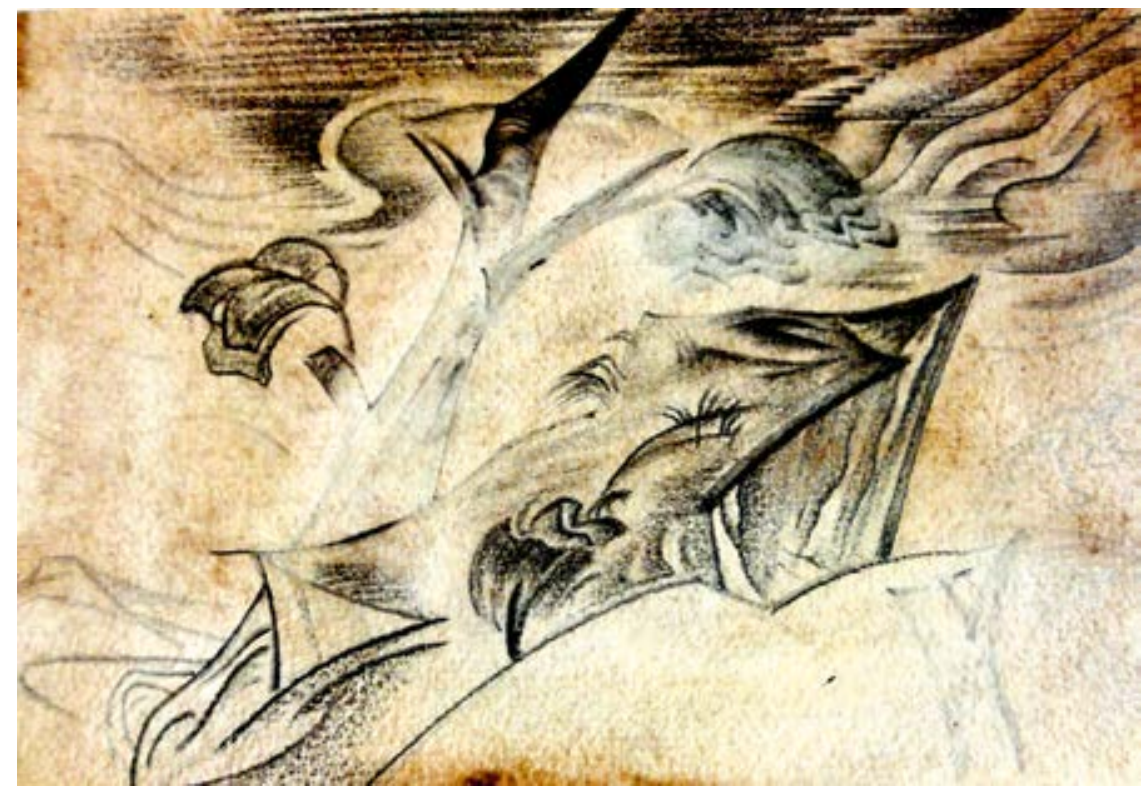

9.

Bronisław Jamontt, Landscape, pencil, paper, 1920s, $\quad$ Bronisławas Jamonttas, Peizažas, XX a. 3 deš. National Museum in Warsaw

separated by a path, revealing the striving for symmetry. In the Pejzaciz $z$ kaskada [Cascade landscape] (around 1924, National Museum in Warsaw), rocks, characteristic for earlier compositions, only fill the sides of the layout. Its core is separated by the bed of a meandering river, whose shape corresponds to wavy and semi-circular lines, determining the rhythm of hills and clouds. This work illustrated the first part of the report from the Arts and Crafts Exhibition in Vilnius which was opened in September 1924 by Feliks Lubierzyński. Focusing on the Vilnius painting milieu, which, according to critics, was dominated by Ludomir Sleńdziński, he devoted the most space to Jamontt, recognising him as "original creative individuality," assessing his oeuvre as follows: "This artist does not recreate nature, but composes, processes the shapes observed in nature employing rhythmically connected lines and colours of not too extensive scale, but in strong contrasts imposed, a kind of painting symphonies, it gives fantastic, fairytale landscapes, yet they speak with vivid mood expressed in them. In the series of landscapes of 


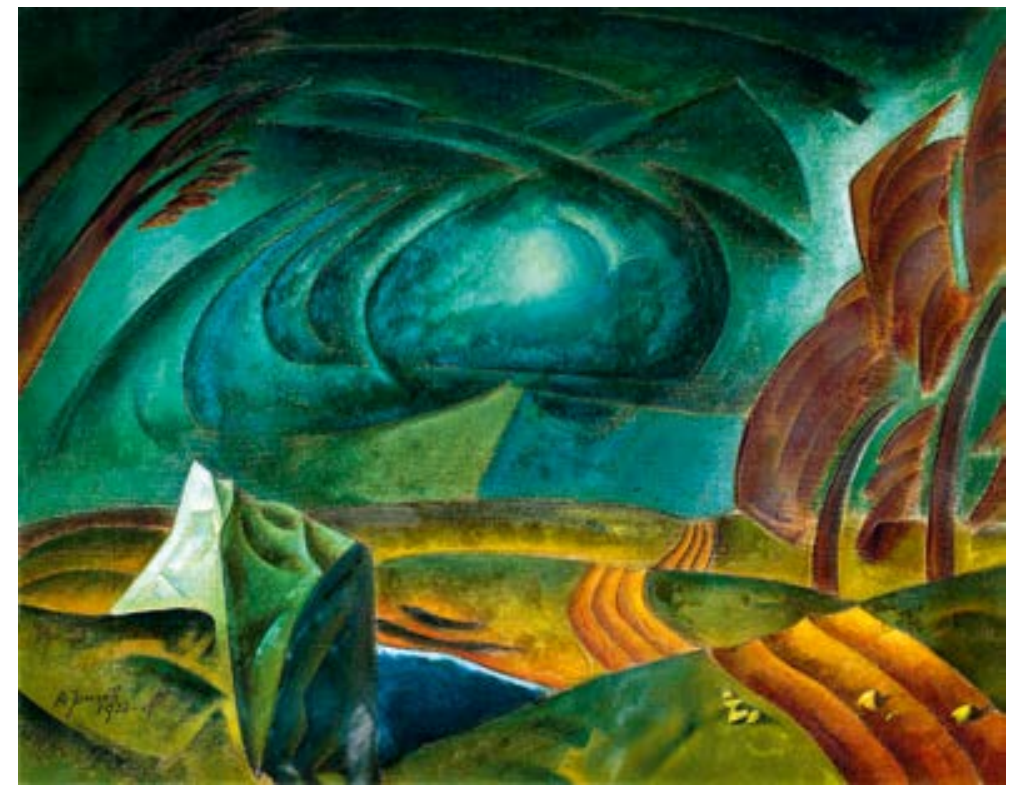

10.

Bronisław Jamontt, Formist Landscape With a Lake and Road (Fantastic Landscape), 1923-1924, oil, canvas, National Museum in Warsaw
Bronisławas Jamonttas, Formistinis peizažas su ežeru ir keliu (Fantastinis peizažas), 1923-1924

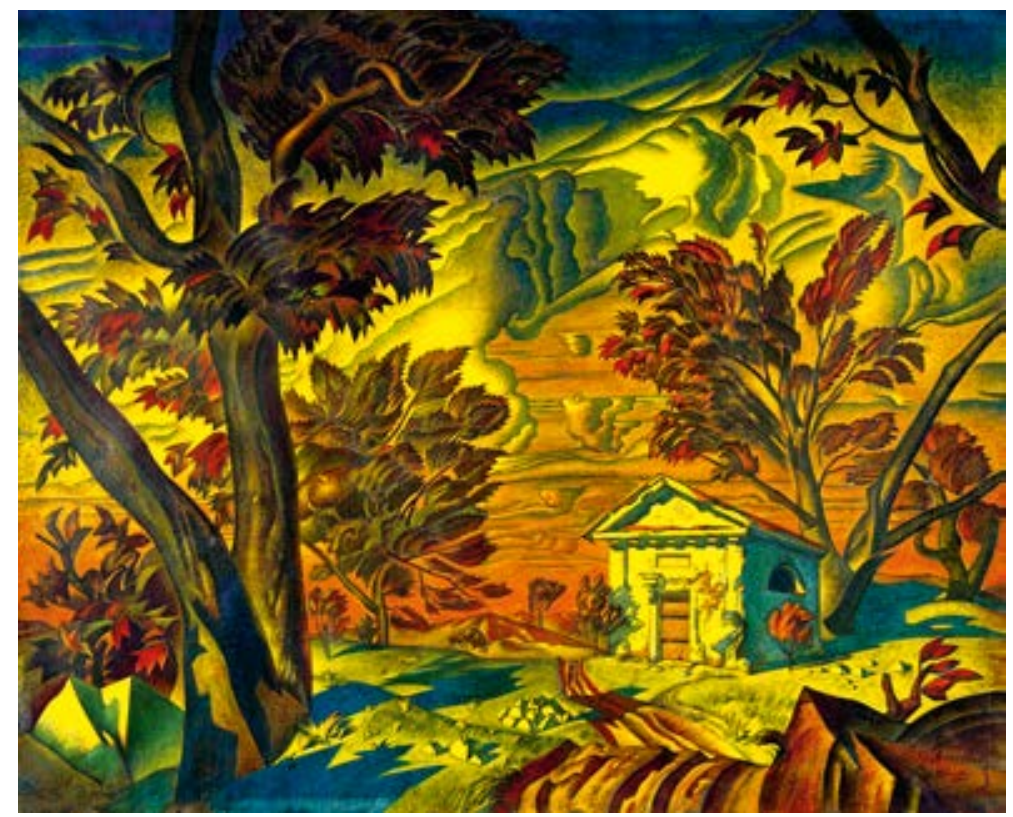

11.

Bronisław Jamontt, Landscape with a Wayside Shrine, 1925, tempera covered with wax varnish, paper, District Museum in Torun
Bronisławas Jamonttas, Peizažas su pakelès šventove, 1925 
Wilno, realistically depicted in the drawing and a little monotonous in colourful harmony, Jamontt is perhaps painting-wise better, but less engaging"'15.

Stronger emphasis on the realistic element is also brought by the Pejzaż z kapliczka [Landscape with a wayside shrine] (1925, District Museum in Torun), also referring to the romantic vision of nature [illus. 11]. In this case, the classicist temple, which is a small element of the composition, seems to be annexed by the trees and clouds towering over it, thus manifesting that in a clash with the forces of nature, man's work stands no chance. Compared to previous works, the tempera discussed here draws attention to the details, which is particularly evident in the meticulous development of the leaves. The power of the elements also took over the gouache Pejzaz $z$ dwoma czerwonymi domkami [Landscape with two red houses] (1929, National Museum in Warsaw). One-story buildings with high, sloping roofs, resist hurricane wind, deflecting trees, almost overwhelmed by piles of clouds.

The impression of monumentalism accompanies a series of works showing the historic buildings of Vilnius. Taken slightly from below, they fill almost the entire workspace. Further, drawn with charcoal (1925, Kościót Franciszkanów w Wilnie [Franciscan Church in Vilnius], National Museum in Warsaw; 1925, Kościót Bernardynów [Bernardine Church], National Museum in Warsaw; 1927, Kamienica Kapitulna przy ul. Zamkowej w Wilnie [Kapitulna apartment house at Zamkowa in Vilnius], National Museum in Warsaw) usually focus on a fragment of the façade, giving it structure, drawn with sharp vertical and horizontal lines [illus. 12].

Another interesting group constitute the depictions of less representative corners of Vilnius. Alleys, yards, gates, crumbling buildings all are becoming an attractive topic for Jamontt. Selected motifs give the impression of "living with their own life." Sloping roof edges, fallen-outdoors, crooked windows, uneven pavement introduce incredible dynamism, additionally enhanced by thickly applied paint, creating a vibrating colour tissue. Jamontt's sense of observation, combined with an emotional attitude to the surrounding space, resulted in sceneries revealing the beauty in seemingly unimpressive places to which the artist returned many times (1928, Podwórko w Wilnie [Yard in Vilnius], District Museum in Toruń; 


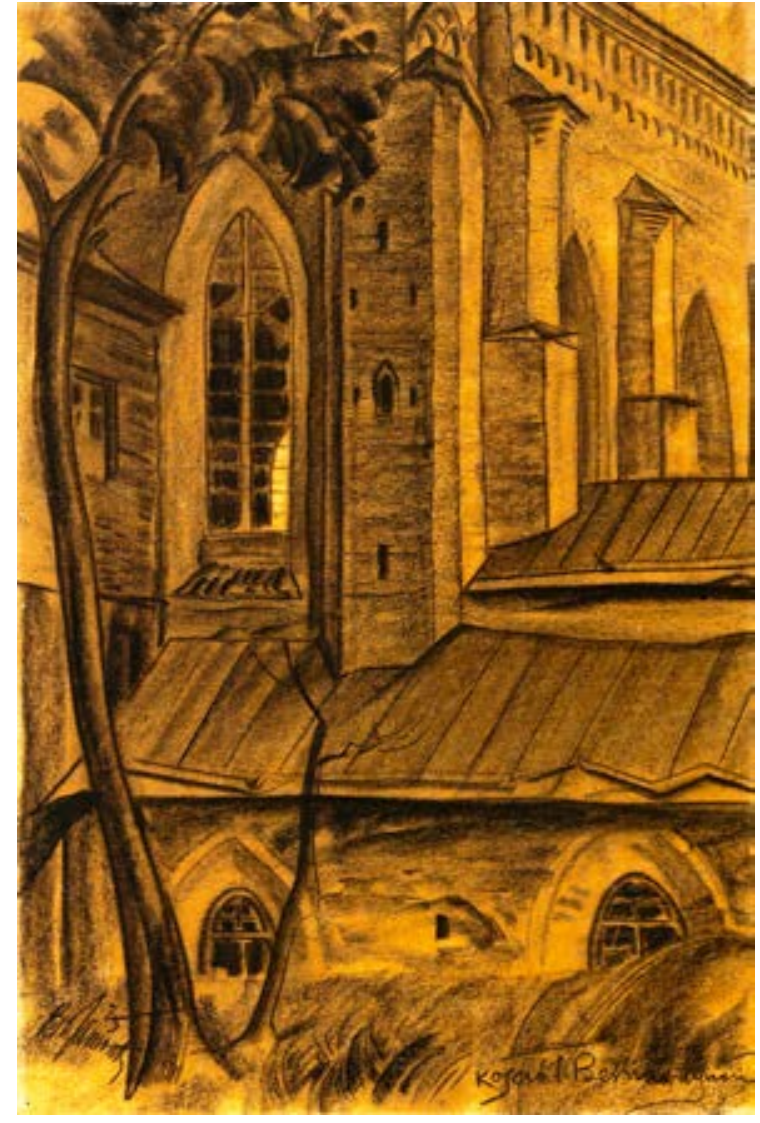

12.

Bronisław Jamontt, Bernardine Church, 1929, coal, paper, National Museum in Warsaw

Bronisławas Jamonttas, Bernardinu bažnyčia, 1929

1929, Zautek [An alley], National Museum in Warsaw). The fragments of the Jewish quarter remained a frequent motive. Using a convergent perspective, the artist guided the viewer's eyes deep into narrow streets, tightly built, differing in the colours of the facades, on which the sun's rays wander, piercing dark clouds (1934, Uliczka żydowska w Wilnie [Jewish street in Vilnius], District Museum in Toruń) [illus. 13] ${ }^{16}$. It is this group of works that best reflects the genius loci of the city on the Neris and which was compared with the output of Jerzy Hoppen in the article by Jerzy Wyszomirski - "Miasto kontrastów" [City of contrasts]. According to the author of the text: "Jamontt's paintings are winding, twisted and confusing, like the corners of the Vilnius ghetto, like the courtyards and cortiles here,

16 Anna Kroplewska-Gajewska, Galeria Malarstwa i Rzeźby Polskiej od końca XVIII do poczatku XXI wieku w Muzeum Okregowym w Toruniu / The Gallery of Polish Painting and Sculpture from the late 18th to the early 21st century in The District Museum in Torun: Katalog / Catalogue, Torun, 2018, pp. 271-272. 


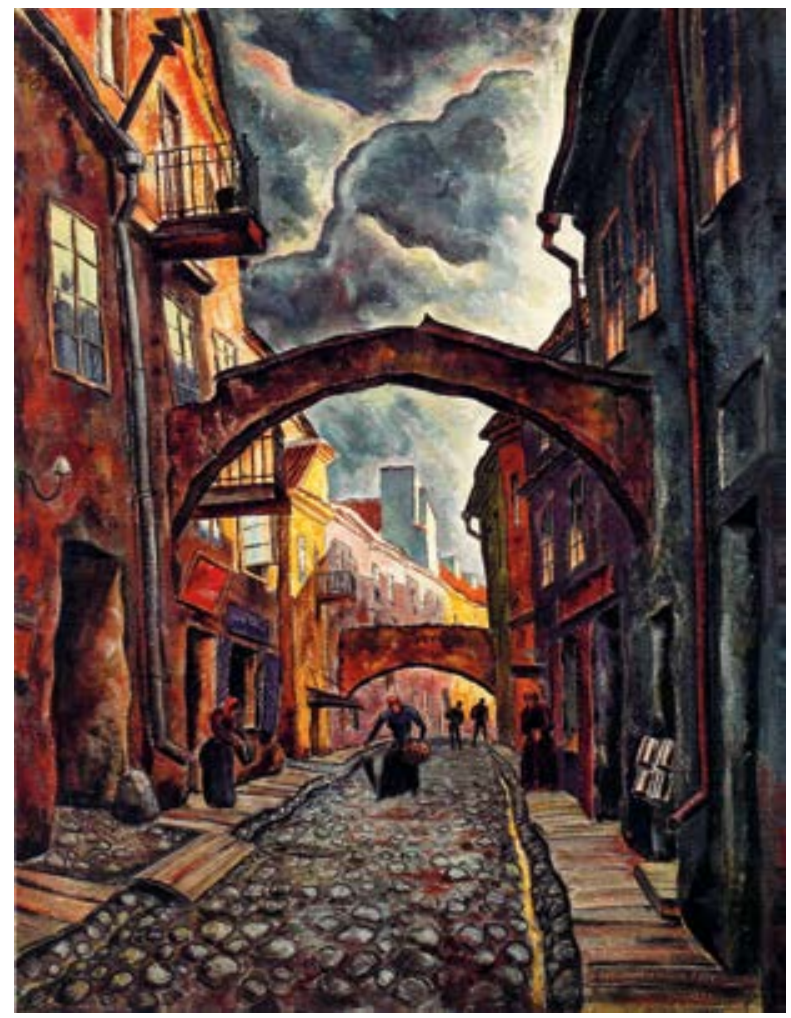

13.

Bronisław Jamontt, Jewish Alley in Vilnius, 1934, tempera, cardboard, District Museum in Toruń

Bronisławas Jamonttas, Žydu gatve Vilniuje, 1934

like the cobbles of Vilnius streets. Gloomy shadows contrast with them, with bright patches of light, as in our alleys, when the sun barely breaks into their zigzag gorges. If a human figure appears in these paintings, it is usually an old Jew or a miserable street vendor: for such people live in these alleys, dark and old, bound, strengthened with many arcades. Old age, mould, moisture, mossiness - captivating and mysterious. This is one face of Vilnius. Others - Hoppen's attraction: Vilnius of the 17th century, baroque, lordly and magnificent, Vilnius of delicious churches and palaces, ambitious, proud and powerful"17.

Both artists were associated with the Faculty of Fine Arts of the Stephen Báthory University in Vilnius, where, in 1931, they both began teaching. Hoppen was Head of the Graphic Arts Department, and Jamontt was employed at the Department of Landscape Painting as a senior assistant to 
Professor Ferdynand Ruszczyc, who saw him as his successor. Formally, in 1934 the artist graduated from the studies started in 1928. In 1936 he was appointed Ruszczyc's deputy, and in 1937 as Associate Professor of Landscape Painting at the Faculty of Fine Arts of Stephen Báthory University. Between 1928 and 1930, Jamontt visited Paris, Brussels, and Italy. At that time, the sceneries of the places visited were created. The tempera Most Rialto $w$ Wenecji [Rialto Bridge in Venice] (1930, Lithuanian National Museum of Art, Vilnius) is almost documentary in nature. A monument unique for the city was foreshortened. The broken railing line, located above the arch, connecting the banks of the Grand Canal, is balanced by verticals and levels of precisely drawn façades. Wspomnienie z Toskanii [Memoirs of Tuscany] (1934, Lithuanian National Museum of Art, Vilnius), on the other hand, refers to the manner of "painted journeys," a time when Romantic painters roamed the regions of Europe in search of remarkable motifs. The work painted in Vilnius is reminiscent of sensations associated with the journey to Italy. The composition draws attention with its harmonious combination of slightly moving trees, whose round shapes duplicate the swirling clouds, with the silhouette of an old castle, geometric in its simplicity.

At the turn of the 1920s and the 1930s, Jamontt's mature style consolidated as well. Analysing the legacy of this period, one can see that the artist, following the pattern of landscapists from past eras, frequently depicted nature not as it was, but as it should "be." For Jamontt, educated in the academic tradition, the foundation for painting was étude-study from nature, performed directly in the open air. The studies became a resource catalogue of motifs, from which the artist then composed a work that was created, and certainly finished in his studio. The landscapes created in the 1930 s combine real fragments of nature in a theatrical, sometimes even fantastic entity. Spreading old trees, half-dead with twisted boughs, placed in the foreground, and stormy dark swirling clouds became a favourite motif. As Wiktor Podoski noted, "Gnarled trees, heavy sky with piles of clouds. To define these landscapes, you need sharp, rough, lumpy words, like wrinkled old hands. <...> Colour, not neglected, does not scatter into a calm and smooth stain - it drizzles, lives along with the insightful inquisitiveness of

Małgorzata Geron _— Dialogue of Modernity and Tradition in the Landscapes by Bronistaw Jamontt from the Interwar Period 


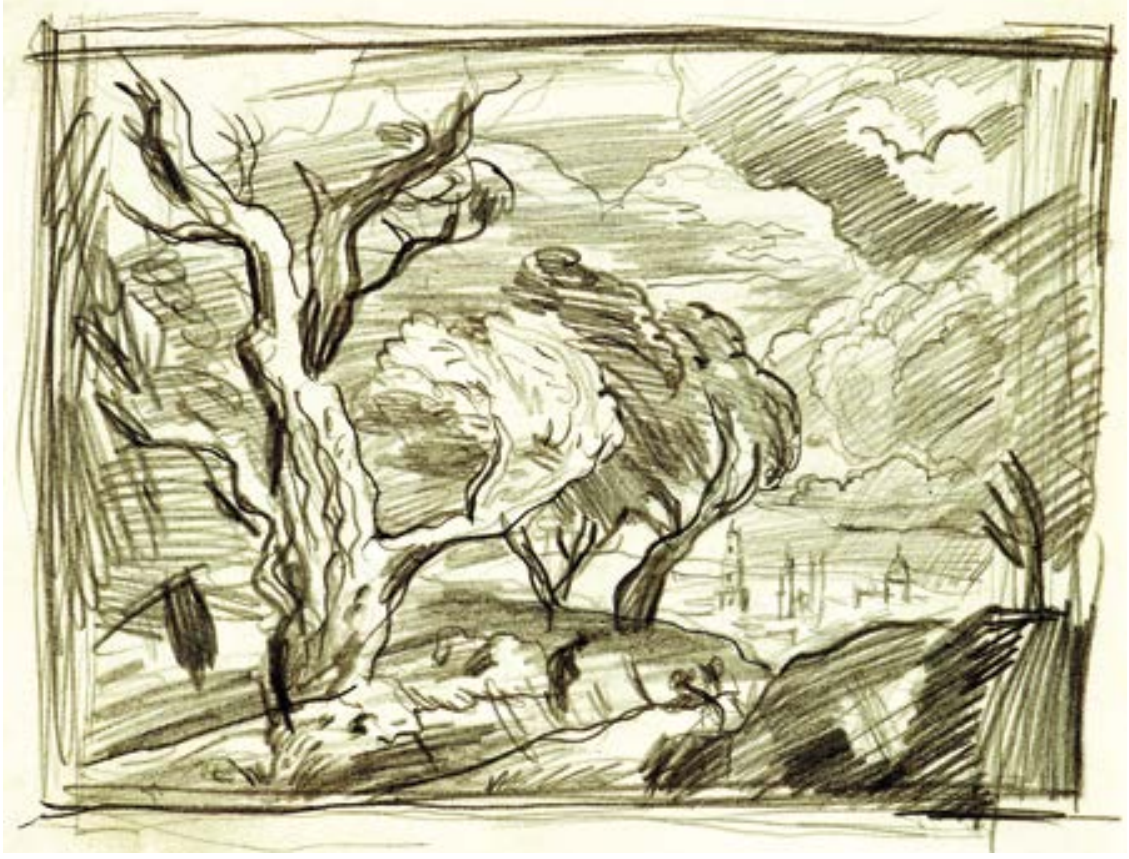

14

Bronisław Jamontt, Landscape with the City in the Distance, pencil, paper, District Museum in Torun

Bronisławas Jamonttas, Peizažas su miestu tolumoje

the drawing"18. The artist's sketchbooks usually fill the representations of trees; sometimes, they are only outlines recorded with a quick, nervous line, at other times polished compositions divided into boxes, ready to be transferred to the canvas.

Probably based on the drawing Pejzaz z miastem $w$ oddali [Landscape with the city in the distance] (District Museum in Toruń) Jamontt made the watercolour Pejzaz $w$ czasie burzy [Landscape during a storm] (National Museum in Warsaw), which in turn served as a source for painting the oil Dęby na peryferiach Wilna [Oaks on the outskirts of Vilnius] (1934, Lithuanian National Museum of Art, Vilnius) [illus.14]. The artist's beloved city is visible in the distance, below the horizon, a winding road leads to it. On the left, the artist placed several decades-old oaks, windswept, lit by streaks of light, breaking through the dark banks of clouds. It is not a

18 Wiktor Podoski, “Wystawa Wileńskiego Towarzystwa Artystów Plastyków”, in: $A B C$, 1933, No. 118, p. 5. 


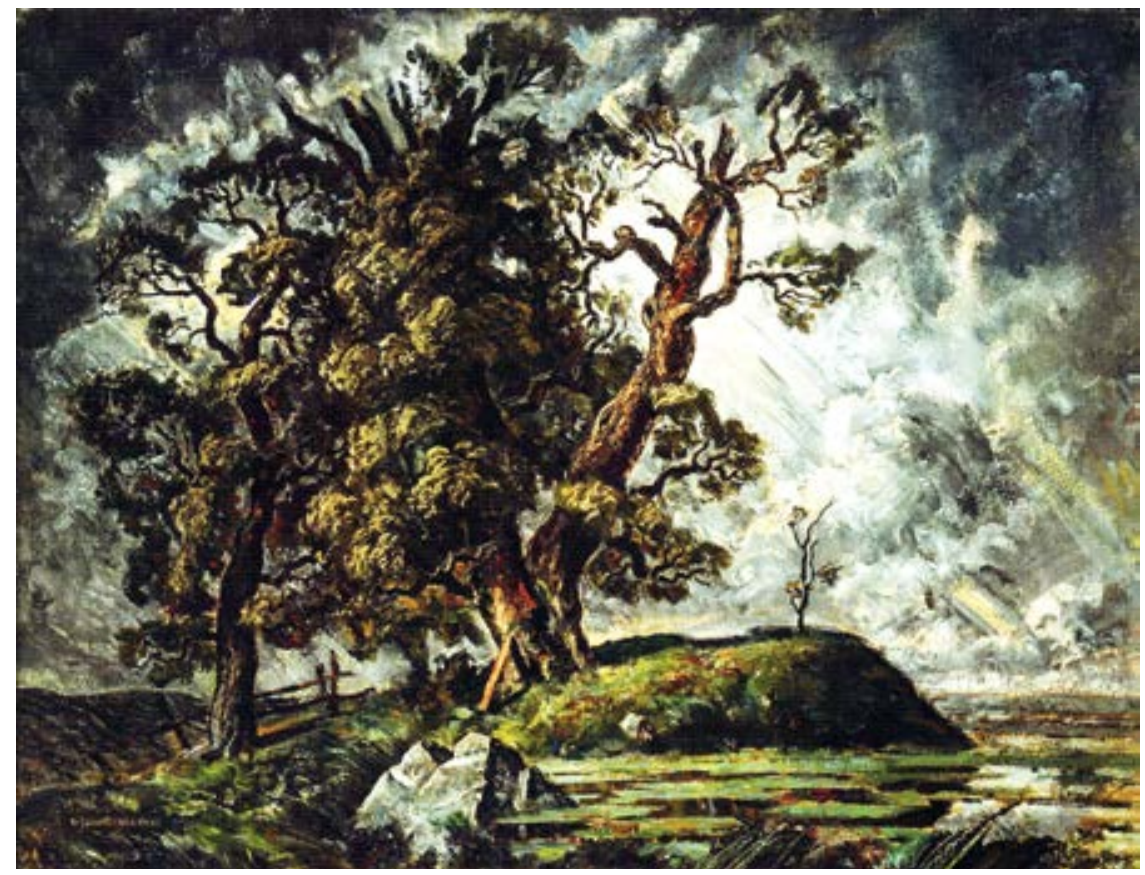

15.

Bronisław Jamontt, Before the Storm, 1938, tempera, ～Bronisławas Jamonttas, Priěs audra, 1938 cardboard, Leon Wyczółkowski District Museum,

Bydgoszcz

coincidence that repeated elements shape the indicative mood of the works, intensified by the effects of chiaroscuro effects, changeable sky, busy clouds, leaf movement, or the distribution of bright and shaded parts, observed directly in nature, which emphasise the dramatic nature of the scenes. Kazimierz Kieniewicz wrote about such paintings as, for example, Przed burza [Before the storm] (1938, Leon Wyczółkowski District Museum in Bydgoszcz) [illus. 15]: "All nature seems to be experiencing some appalling tragedy here. The branches of old oaks, shattered by lightning, bend to the ground under the pressure of a gale, banks of clouds, brightly illuminated with sheaves of light, foaming waterfalls roll down from the cliffs, and the ruins of the castles stand in a sunny glow as if dumbfounded in terror."

Jamontt's drawings were also used by Hoppen, who created prints from them. The woodcuts preserved in the collections of the District 


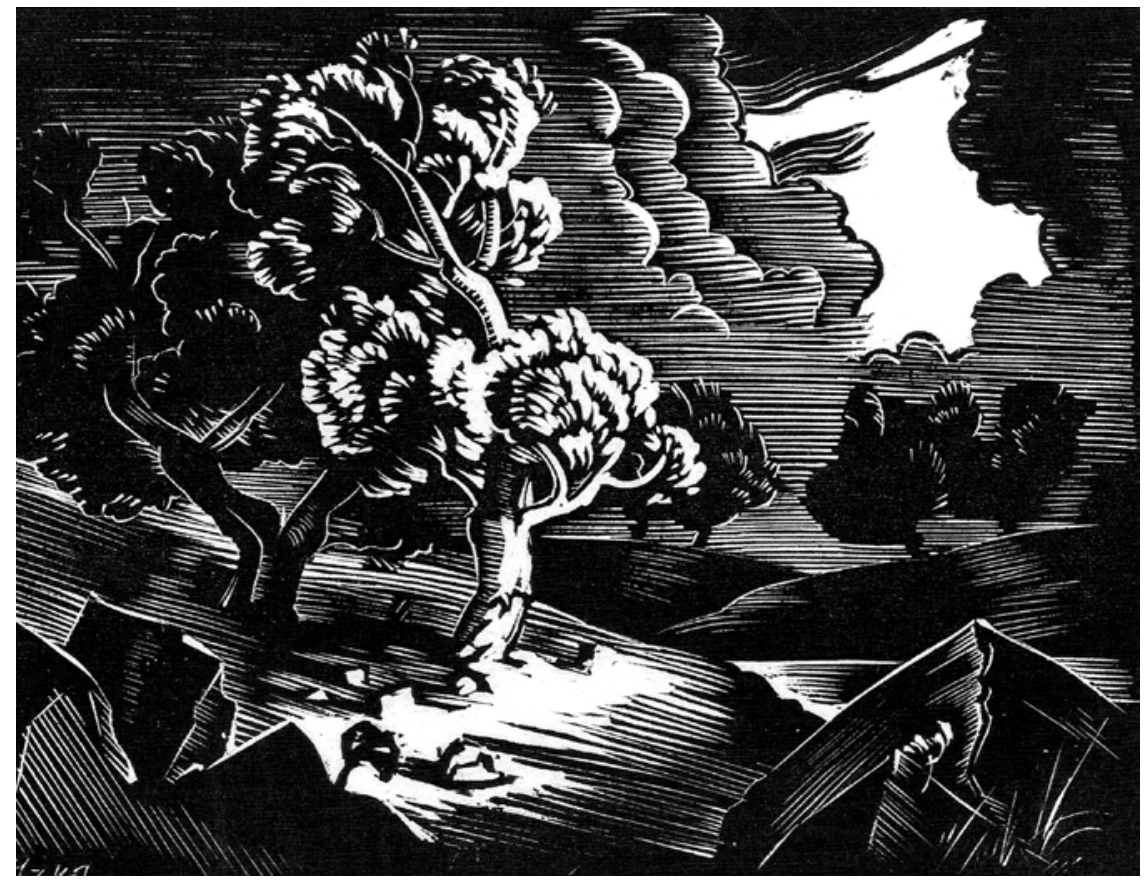

16.

Jerzy Hoppen, Landscape with Trees/Landscape Before the Storm, by Bronisław Jamontt, 1930,

Jerzy Hoppenas, Peizažas su medžiais / Peizažas woodcut, District Museum in Torun.

Museum in Torun and the library of the Nicolaus Copernicus University in Toruń (1930, Pejzaż z drzewami Pejzaż przed burza [Landscape with trees / Landscape before the storm] and Stary dab [Old oak]) show the extensive trees torn apart by gusts of wind ${ }^{19}$ [illus. 16]. Hoppen admired Jamontt's work. His appreciation is proven by his article bearing the eminent title "Artyzm Bronisława Jamontta" [The artistry of Bronisław Jamontt], published on the occasion of the painter's last exhibition in Vilnius in early 1939. Focusing on the achievements of the previous few years, he has separated three groups of works in it: sketches and paintings based on the studies from nature and monumental landscape compositions. It was the latter ones that gained him the most recognition, as best reflecting the artist's original style, refusing to follow various influences slavishly. Summing up 
his considerations, he stated that: "Jamontt is unique and there is no other artist like him"20.

After World War II, Jamontt, together with other university staff, arrived in Torun, establishing the Faculty of Fine Arts from scratch from what remained within the structure of the Nicolaus Copernicus University, following the Vilnius model. His post-war work was a continuation of his previous experiences. Parts of Vilnius replaced the picturesque alleys of Torun. While creating landscape works, the artist often drew from his old sketches, on the basis of which he composed oil paintings and prints ${ }^{21}$.

Summing up the achievements of the first Dean of the Faculty of Fine Arts of Nicolaus Copernicus University whose monographic exhibition, celebrating the 30th anniversary of his creative work, took place in Torun in 1947, it is worth turning to the words of Jerzy Hoppen, who emphasising the high level of the professor's work focused on the theme of landscape, stressing that "he studies from nature as well, but he transforms the material collected in this way into a finished work in his studio, subject to his creative will $[\ldots . .]^{\prime 22}$.

\section{Submitted - 08/01/2020}

20 Jerzy Hoppen, "Artyzm Bronisława Jamontta" [The artisty of Branisłąw Jamontt], in: Stowo, 1939, No. 42, p. 11.

21 Małgorzata Geron, "Artyści wileńscy w Toruniu”, in: Wędrowanie sztuki, ed. Artur Badach and Katarzyna Chrudzimska-Uhera, Warszawa: Stowarzyszenie Historyków Sztuki, 2018, pp. 53-68.

22 Jerzy Hoppen, "Bronisław Jamontt. Z powodu jubileuszowej wystawy w Toruniu", in: Arkona, 1947, No. 4-5, pp. 16-17. 


\section{Bibliography}

ergo. [Kazimiera Adamska-Roubina], "Bronisław Jamontt”, in: Stowo, 1928, No. 40, p. 3.

Geron Małgorzata, "Artyści wileńscy w Toruniu" [Vilnius artists in Toruń], in: Weqdrowanie sztuki, eds. Artur Badach and Katarzyna Chrudzimska-Uhera, Warszawa: Stowarzyszenie Historyków Sztuki, 2018, pp. 53-68.

Hoppen Jerzy, "Artyzm Bronisława Jamontta" [The artistry of Bronisław Jamontt], in: Stowo, 1939, No. 42, p. 11.

Hoppen Jerzy, "Bronisław Jamontt. Z powodu jubileuszowej wystawy w Toruniu”, in: Arkona, 1947, No. 4-5, pp. 16-17.

W. H. [Husarski Wacław], "Z Zachęty. Bronisław Jamontt”, in: Tygodnik Illustrowany, 1934, No. 22, p. 432.

Kieniewicz Kazimierz, "Zbiorowa wystawa prac Bronisława Jamontta" [Collective exhibition of works by Bronisław Jamontt], in: Stowo, 1937, No. 37, p. 7.

Konstantynów Dariusz, Wileńskie Towarzystwo Artystów Plastyków 1920-1939 [Vilnius Society of Visual Artists 1920-1939], Warszawa: Instytut Sztuki Polskiej Akademii Nauk, 2006.

Kotłowski Jan, “Z graficznej i rysunkowej twórczości Bronisława Jamontta” [From the visual and drawing oeuvre of Bronisław Jamontt], in: Studia o działalności $i$ zbiorach Biblioteki Uniwersytetu Mikołaja Kopernika, ed. B. Ryszewski, part. IV, Torun 1991, pp. 37-67.

Kotłowski Jan, "Bronisław Jamontt”, in: https://www.bu.umk.pl/bronislaw-jamontt.

Kroplewska-Gajewska Anna, Galeria Malarstwa i Rzeźby Polskiej od końca XVIII do poczatku XXI wieku w Muzeum Okregowym $w$ Toruniu / The Gallery of Polish Painting and Sculpture from late 18th to early 21st centuries in The District Museum in Toruń: Katalog / Catalogue, Toruń: Muzeum Okręgowe w Toruniu, 2018.
Krzysztofowicz-Kozakowska Stefania, Sztuka Mtodej Polski [Young Poland's art], Kraków: Wydawnictwo Kluszczyński, [2003], p. 178.

Kubaszewska Hanna, Liczbińska Maria, Załęska Hanna, "Jamontt Bronisław", in: Stownik artystów polskich i w Polsce działajacych, Vol. III, ed. Jolanta MaurinBiałostocka, Wrocław-Warszawa-KrakówGdańsk, 1979, pp. 188-191.

Lubierzyński Feliks, "Z Wystawy Sztuki i Rzemiosł w Wilnie (I. Malarstwo)" [From the Arts and Crafts Exhibition in Vilnius (I. Painting)], in: Wileński Przeglad Artystyczny, 1924, No. 4, p. 2.

Malinowski Jerzy, "Kultura artystyczna Wilna 1893-1945" [Vilnius artistic culture 1893-1945], in: Wileńskie środowisko artystyczne 1919-1945, Olsztyn: Galeria Sztuki Współczesnej BWA, 1989, pp. 15-41.

"Pierwsza doroczna wystawa Wileńskiego Towarzystwa Artystów Plastyków" [The first annual exhibition of the Vilnius Society of Visual Artists], in: Potudnie, 1922, No. 3, p. 58.

Podoski Wiktor, "Wystawa Wileńskiego Towarzystwa Artystów Plastyków" [Exhibition of the Vilnius Society of Visual Artists], in: $A B C, 1933$, No. 118, p. 5.

Poklewski Józef, Polskie życie artystyczne w międzywojennym Wilnie [Polish artistic life in Interwar Vilnius], Torun: Wydawnictwo Uniwersytetu Mikołaja Kopernika, 1994.

Przybyszewski Stanisław, "Confiteor”, in: Programy i dyskusje literackie okresu Młodej Polski [Literary programs and debates of the Young Poland period], ed. Maria Podraza-Kwiatkowska, Wrocław-Warszawa-Kraków-Gdańsk: Zakład Narodowy im. Ossolińskich, 1977, pp. 235-243.

Przybyszewski Stanisław, $\mathrm{Na}$ drogach duszy [On the roads of the soul], Kraków: L. Zwoliński i Spółka, 1900, p. 51.

Puciata-Pawłowska Jadwiga, "Krajobraz B. Jamontta (na marginesie wystawy w toruńskim Domu Plastyków)" [B. Jamontt's
$98-2020$

Acta Academiae Artium Vilnensis 
landscape (in the fringe of the exhibition at the House of Artists in Toruń)], in: Gtos Pomorza, (27.04), 1947, p. 4.

Puciata-Pawłowska Jadwiga, "Droga Bronisława Jamontta” [Bronisław Jamontt's path], in: Pomorze, 1955, No. 3, p. 15.

Remer Jerzy, “Oblicze artystyczne B. Jamontta" [The artistic visage of B. Jamontt], in: Gtos Pomorza, (14.04), 1947.

Rissmann Agata, Bronistaw Jamontt 1886-195\%. Malarstwo. Rysunek [Bronisław Jamontt 1886-1957. Painting. Drawing], Toruń: Muzeum Okręgowe w Toruniu, 2011, p. 30.

Rissmann Agata, Stenka Szymon Jan, Jerzy Hoppen 1891-1969. Artysta, konserwator, profesor [Jerzy Hoppen 1891-1969. Artist, conservator, professor], Toruń: Muzeum Okręgowe w Toruniu, 2018.

Širkaitè Jolanta, Académie de Vilna. Vilniaus piešimo mokykla / Vilnius Drawing School 1866-1915: Parodos katalogas / Exhibition Catalogue, Nacionalinè dailès galerija, 2017 m. spalio 4 d. - lapkričio 26 d., Vilnius: Lietuvos kultūros tyrimų institutas, 2017, p. 188.

Winkler Konrad, Formiści polscy [Polish Formists], Warszawa: Nakład Gebethnera i Wolfa, 1927, p. 19.

Wyszomirski Jerzy, "Miasto kontrastów" [The city of contrasts], in: Wiadomości Literackie, 1934, No. 33, p. 8. 
Santrauka

\section{Dialogas tarp modernybès ir tradicijos Bronisławo Jamontto tarpukario peizažuose}

Małgorzata Geron

Reikšminiai žodžiai: Bronisławas Jamonttas, tapyba, peizažas, tarpukaris, Vilniaus meninè aplinka, Vilniaus piešimo mokykla, Stepono Batoro universiteto Dailès fakultetas.

Žavėjimasis gamta skleidžiasi visoje Bronisławo Jamontto kūryboje. Ankstyvojo laikotarpio kūriniams charakteringas autentiškas tikrovès vaizdavimas. Kontaktai su Krokuvos-Zakopanès kūrybinėmis bendruomenėmis inspiravo Jamonttą pasirinkti tinkamiausias formalias priemones, leidusias jautriai fiksuoti gamtos keliamus pojūčius. I̦kvèptas avangardistų paieškų XX a. 3 deš. Jamonttas ėmė kurti fantastiškus peizažus, kuriuose figūruoja kosminèje erdvejje sklandančios uolos. Transformuotos šių peizažų formos ir fantastiška spalvų paletė kuria nerimo ir paslapties atmosferą. 4 deš. menininkas grị̌zo prie realistinių elementų ir ėmèsi kurti iš natūros pieštais eskizais paremtus stilizuotus peizažus, kuriuose išryškejja romantiška gamtos vizija. 